\title{
ENTRE EL RECONOCIMIENTO Y LA INCONSULTA: LOS DERECHOS INDÍGENAS EN LA REFORMA DEL CÓDIGO CIVIL Y COMERCIAL ARGENTINO
}

\section{Gina Paola Rodríguez Montenegro ${ }^{1}$}

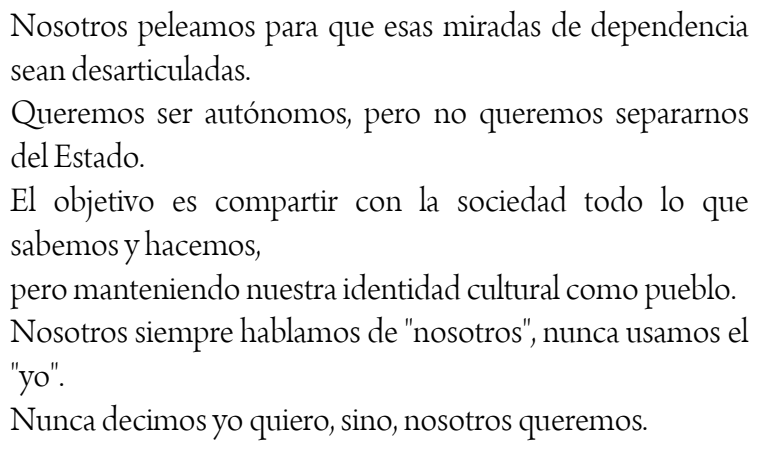

Félix Díaz. Dirigente Qom

\section{Resumen}

El trabajo reconstruye y analiza el proceso de inclusión de los derechos indígenas en el proyecto de reforma y unificación del código civil y comercial argentino. Se sostiene que este proceso reedita tres nudos problemáticos del diálogo intercultural: la incompatibilidad de las visiones occidental e indígena bajo la grilla del derecho privado; las dificultades para incorporar las vindicaciones indígenas en los dispositivos y ámbitos institucionales abiertos por el Estado; y las aporías de la implementación de las políticas de la diversidad cultural en tiempos del avance del modelo neoliberal y su sucesor, el neo-desarrollismo.

Palabras Clave: Derechos indígenas - código civil y comercial-Argentina- interculturalidad

\section{INTRODUCCIÓN}

El 8 de junio de 2012 el Poder Ejecutivo Nacional envió al Senado de la República el proyecto de Reforma y unificación del Código Civil y Comercial que buscó actualizar el de 1871 tras catorce décadas de transformaciones. Dentro de los puntos a legislar se encontraban los derechos indígenas que, si bien habían sido reconocidos en la reforma constitucional de 1994, se hallaban sin definición plena hasta la fecha, salvo por algunas leyes federales y provinciales. El Proyecto elaborado por la Comisión redactora $(2011)^{2}$, incluyó temas como el

\footnotetext{
${ }^{1}$ Docente e investigadora de la Universidad de Buenos Aires. E-mail: paolitarodriguez1789@gmail.com

${ }^{2}$ La Comisión redactora integrada por los Doctores Ricardo Lorenzetti, Elena Highton de Nolasco y Aída Kemelmajer de Carlucci elevó el anteproyecto de Código Civil y Comercial de la Nación al Poder Ejecutivo el 24 de febrero de 2012. El Poder Ejecutivo Nacional recibió el anteproyecto y realizó una serie de modificaciones que se discutieron hasta noviembre de 2013, fecha en la que el Poder legislativo aprobó el nuevo código.
} 
derecho indígena, el derecho colectivo, el derecho a la preexistencia, el carácter de la personalidad jurídica de los pueblos originarios, el territorio, la posesión y la propiedad comunitaria indígena y la consulta y participación de los indígenas en la toma de decisiones que afecten sus territorios.

Tras conocer el anteproyecto presentado por el Presidente de la Corte Suprema de Justicia de la Nación, Ricardo Lorenzetti, ONG's de derechos humanos y organizaciones indígenas manifestaron su inconformidad frente a lo que consideraron una propuesta de carácter inconsulto, unilateral y negador de la cosmovisión indígena, además de inconstitucional, e iniciaron una campaña en contra de la inclusión de los derechos indígenas en el nuevo código civil (Consejo Plurinacional Indígena, 2012; CELS et al 2012; ODHPI 2012; ENDEPA, 2012). Por otra parte, organizaciones de pueblos originarios como el Encuentro Nacional de Organizaciones Territoriales Indígenas - ENOTPO- manifestaron su beneplácito por la inclusión de éstos derechos en el ámbito de regulación del código civil aunque sugirieron su reformulación en una propuesta de mayor amplitud y cobertura que esperaban fuera incluida en el texto definitivo de la reforma (ENOTPO, 2013).

El debate en torno a la pertinencia del código civil como instancia para la reglamentación de los derechos indígenas reeditó un buen número de tensiones y problemas irresueltos en torno a la gestión estatal de la diversidad étnica: ¿Cómo moldear jurídicamente al sujeto indígena? ¿Cómo enmarcar un espacio existencial como el territorio dentro de los límites del derecho de propiedad? ¿Cómo hacer que el código civil entienda en materia de derechos colectivos y bienes comunes? Estas y otras cuestiones atravesaron la totalidad del proceso poniendo de presente las dificultades del Estado argentino para conciliar los principios de preexistencia, autonomía y libre determinación de los Pueblos Originarios con la reglamentación jurídica del derecho privado, esto es, para avanzar en la incorporación de principios propios de una visión holista, tradicional y colectivista del mundo dentro de un paradigma jurídico individualista y privatista

A propósito de la controversia suscitada por la reforma, el presente trabajo reconstruye y analiza el debate adelantado por la sociedad civil en la periferia del Senado. Si bien éste último descartó buena parte de los temas incluidos en el anteproyecto, el seguimiento de las posturas adoptadas por las organizaciones sociales en el marco de las consultas públicas y abiertas, permite entrever los principales puntos de discusión en torno a los mecanismos de intervención estatal en la reglamentación de los derechos de los pueblos originarios. Así mismo, proporciona algunas coordenadas del mapa de actores interesados en participar en el modelado de los derechos indígenas y sus retóricas divergentes, dando cuenta de la variedad de comprensiones e intereses que circulan sobre la materia. Finalmente, hace posible visibilizar la heterogeneidad de posturas y las tensiones al interior de las organizaciones de Pueblos Originarios en torno a los modos de concreción de sus derechos en el plexo jurídico.

El artículo se estructura en tres partes. En la primera reconstruimos, a manera de antecedentes, las principales políticas desplegadas por el Estado argentino hacia los Pueblos originarios a lo largo del siglo XX, las 
inflexiones operadas por el cambio constitucional de 1994 y los bemoles del "garantismo cultural" de las políticas neo-indigenistas en sus etapas neoliberal y neodesarrollista. A continuación, nos concentramos en la discusión sobre los derechos indígenas propuesta en el anteproyecto de reforma y unificación del código civil y comercial, atendiendo a las posturas divergentes respecto del articulado planteado y las contra-propuestas. Finalmente, analizamos el texto aprobado por el Senado en noviembre de 2013 adentrándonos en los efectos que este breve pero definitivo articulado tiene en términos del reposicionamiento de los indígenas como sujetos del derecho privado. Vale aclarar que el proceso de aprobación del nuevo código civil y comercial por parte de la Cámara de Diputados se mantiene en suspenso al momento de escribir este artículo, por lo que las conclusiones aquí esbozadas deben asumirse como provisorias.

Allende la coyuntura, sostenemos que la propuesta de inclusión de los derechos indígenas en el proyecto de reforma del código civil y comercial reedita tres nudos problemáticos del diálogo intercultural: la incompatibilidad de las visiones occidental e indígena bajo la grilla del derecho privado; la difícil incorporación de las vindicaciones indígenas en los dispositivos y ámbitos institucionales previstos por el Estado liberal; y las aporías de la implementación de las políticas de la diversidad cultural en tiempos del avance del modelo neoliberal y su sucesor, el neo-desarrollismo.

\section{NOSOTROS Y LOS “OTROS”}

Como ha sido reiteradamente documentado (Halperín-Donghi 1982; Carrasco 2000; Sarasola 1992), el proyecto decimonónico de Estado- nación en Argentina tuvo como uno de sus principales atributos el apego a un ideal civilizatorio identificado con la matriz cultural europea y la consecuente eliminación de aquellos elementos considerados "bárbaros". Clasificados dentro de este último grupo, los indígenas que habitaban La Pampa, la Patagonia y el Gran Chaco fueron objeto tanto de persecución y eliminación en las campañas militares, como de desplazamiento interno con miras al fomento del capitalismo agrario, e invisibilización y silenciamiento a través de políticas de blanqueo. Las tierras originalmente habitadas por los pueblos indígenas fueron ocupadas por los europeos y sus descendientes criollos. En algunas regiones, los originarios fueron asimilados como "siervos" por los dueños de las tierras, mientras que en otras, fueron desplazados y exterminados. El indígena ocupó desde entonces una posición liminar en los relatos nacionales: excluido en su condición de salvaje e indomable y confinado a la prehistoria de la nación, pero incluido como "contraparte" de la nación civilizada floreciente.

Más allá de los discursos hegemónicos que referían a una supuesta extinción del componente aborigen, el Estado argentino desplegó distintos dispositivos para controlar a los indígenas que sobrevivieron a las campañas militares bajo modalidades asimilacionistas que incluyeron su vinculación a las economías locales como trabajadores rurales estacionales, su proletarización y envío a las zonas urbanas y su promoción como pequeños 
productores. La política de una "nación sin indios", hizo imperativo el disciplinamiento de los sobrevivientes y su docilización por medio del trabajo. Entre 1916 y 1946, la Comisión Honoraria de Reducciones de Indios, en el ámbito del Ministerio del Interior, «fue la institución encargada de transformar a los grupos indígenas en sujetos civilizados con el claro objetivo de disolver su indigeneidad» (Gordillo y Hirst 2012:22). Se trataba de una política de corte paternalista que consideraba que los indígenas eran incapaces de comprender el funcionamiento de la sociedad civilizada y que debían por tanto ser comandados por el Estado.

El arreciamiento de las condiciones de explotación de los indígenas sentó por primera vez la discusión acerca de su reconocimiento como sujetos con plenos derechos a finales de la década del veinte, un planteo que se dio en relación con su condición de trabajadores y no con su particularidad étnica. Esta fue la clave en la que el gobierno de Edelmiro Farrel (1944- 1946) entendió la "cuestión indígena” cuando transformó la Comisión Honoraria de Reducciones de Indios en la Dirección de la Política Aborigen bajo la órbita del Ministerio de Trabajo.

La respuesta del Presidente Perón a las demandas indígenas se mantuvo en la misma línea, aunque estuvo ambientada por una movilización inédita: "el Malón de la paz", una marcha pacífica de los kollas de Salta y Jujuy hasta la ciudad de Buenos Aires cuyos resultados fueron, cuando menos, ambiguos. Si bien por primera vez en la historia los indígenas fueron recibidos por el presidente y homenajeados por el Congreso, su retorno forzado por acción de la Policía Federal; las declaraciones de Perón, en el sentido de «los integrantes del Malón de la Paz no representaban las inquietudes ni las aspiraciones de los auténticos habitantes indígenas de nuestro norte» (Citado por Valko 2007); y el fracaso en la consecución de los títulos de tierras que los marchantes reclamaban, dejaron todo menos un gusto a victoria.

No estamos en capacidad de establecer en qué medida los indígenas de aquel entonces fueron interpelados por el discurso de los cabecitas negras, como sugieren Gordillo y Hirst: «una forma vivida, aunque velada, de reconocer lo indígena como una presencia ausente, en este caso, a través de la clara presencia de sangre indígena en buena parte de la población» (2012:25). Si nos acogemos a las medidas adoptadas por el Gobierno peronista, encontramos que los indígenas adquirieron derechos de ciudadanía y documentos de identidad y se vieron beneficiados tangencialmente por el estatuto del peón y por la abolición de la renta del trabajo a los campesinos (Tesler 1989). Por otra parte, fueron objeto de políticas paternalistas como la recuperación de tierras expropiadas para su beneficio, y algunas medidas incluidas en los Planes Quinquenales donde el Gobierno declaró la necesidad urgente de que el indígena llegase a ser dueño de su tierra, y de que el Estado interviniese directamente en las relaciones entre los indígenas y el resto de la comunidad. El modo de relación que primó fue el de un Estado protector que buscó que los indígenas fuesen educados y absorbidos, involucrados productivamente en la vida de la nación, como parte del Pueblo y no en su condición étnica o cultural diferencial. Su participación, 
se dio como parte de una gran masa social: los humildes, aquellos llamados por Perón a componer el proyecto político de "Una sola Nación”.

Con los gobiernos militares de mediados de los cincuenta desaparece la Dirección de Protección del Aborigen y la política indígena deambula erráticamente entre distintas secretarias, direcciones y servicios nacionales hasta entrados los años ochenta. Como novedad, se realizó en 1968 el primer censo indígena, cuyos resultados subestimaron la población realmente existente en el territorio, dados los criterios y mecanismos escogidos para la medición: la contabilización exclusiva de los indígenas que mantuvieran sus lenguas nativas y habitaran regiones rurales cercanas a los lugares tradicionales pre-hispánicos. Los indígenas que habían migrado a zonas urbanas o residían en asentamientos pequeños, así como aquellos que habían perdido su lengua y costumbres por los procesos de asimilación, quedaron fuera de las mediciones estatales.

Con todo y esto, el censo implicó un avance sustantivo en los dispositivos del gobierno, que discurrió en paralelo con el aumento del activismo indígena, ahora auspiciado por las organizaciones católicas y protestantes y por los sectores de izquierda y del peronismo que asumieron la causa indígena como parte de su crítica al establecimiento. Varias organizaciones y encuentros indígenas vieron la luz en la década del setenta aun cuando no existían criterios unificados en torno a los objetivos de la lucha, haciendo que éstos oscilaran entre las demandas políticas y económicas, por un lado, y las reivindicaciones identitarias y culturales, por otro. A partir de 1975, las organizaciones indígenas fueron fuertemente reprimidas, cuando no cooptadas por los gobiernos provinciales, y las reminiscencias del binomio civilización- barbarie reaparecieron en la visión militar que conmemoró el centenario de las campañas del desierto en 1979. Así, los discursos de la dictadura pusieron al "indio" y al "subversivo" como parte de las fuerzas malignas que impedían el desarrollo de la nación.

Hubo que esperar al retorno de la democracia para que resurgiese la militancia indígena. Anticipándose a lo que vendría a ocurrir en el resto de América Latina, las provincias argentinas fueron pioneras en la promulgación de legislaciones indigenistas. En noviembre de 1984, Formosa declararía la primera Ley Integral del Aborigen (N 426), copiando el "Estatuto de comunidades indígenas" ( ${ }^{\circ}$ 904) de la República del Paraguay. ${ }^{3}$ La medida fue replicada por las Provincias de Salta (ley 6.373 de 1986), Chaco (ley 3.258 de 1987), Río Negro (ley 2.287 de 1988), Misiones (ley 2.435 de 1987 -luego derogada y reemplazada por la ley 2.727 de 1989) y Chubut (ley 3657 1991) (Carrasco, 2000). A las leyes provinciales se sumarían más tarde las leyes nacionales 23.162 de "Nombres aborígenes o derivados de voces aborígenes autóctonas y latinoamericanas" y 23.302, "sobre Política Indígena y apoyo a las Comunidades Aborígenes" promulgada en noviembre de 1985. Esta última, prescribió en su artículo $1^{\circ}$ :

\footnotetext{
${ }^{3}$ Según cuenta Leone (2013a: 4), «la ley fue elaborada por el IPA, con el asesoramiento del Instituto Provincial de Colonización y Tierras Fiscales. A su vez, el 25 de abril de 1984 el gobernador se reunió con funcionarios de ambos institutos para discutir sobre el proyecto de ley teniendo como objetivo, no tanto el "reconocimiento" y la "reparación» (términos con los cuales se iría nutriendo el debate a lo largo de los meses), sino más bien conseguir un "reordenamiento de tierras en comunidades aborígenes».
} vol.08, nº. 03, Rio de Janeiro, 2015.pp. 1393-1420 
Declára[se] de interés nacional la atención y apoyo a los aborígenes y a las comunidades indígenas existentes en el país, y su defensa y desarrollo para su plena participación en el proceso socioeconómico y cultural de la Nación, respetando sus propios valores y modalidades. A ese fin, se implementarán planes que permitan su acceso a la propiedad de la tierra y el fomento de su producción agropecuaria, forestal, minera, industrial o artesanal en cualquiera de sus especializaciones, la preservación de sus pautas culturales en los planes de enseñanza y la protección de la salud de sus integrantes.

Llama la atención que tanto las legislaciones provinciales como las dos leyes nacionales fueran promulgadas con anterioridad a la aprobación del Convenio 169 de la OIT en 1989, hito internacional del reconocimiento de los pueblos indígenas. Para Hirst y Gordillo (2012) así como para Leone (2013a), el nivel de movilización indígena urgió a las autoridades locales en la necesidad de decretar leyes provinciales que encauzaran las demandas y mecanismos de la protesta indígena, razón que explicaría su carácter pionero respecto de la legislación internacional. Lo anterior no ignora el hecho de que los proyectos de ley se construyesen, como afirma Leone «en la tensión entre la consulta y la inconsulta. Entre la participación de los indígenas y la autopoiesis de un Estado que sencillamente recurrió a los dispositivos de funcionamiento interno a los que se encontraba habituado» (2013a:4).

Lo que nos interesa resaltar del proceso de juridización de la "cuestión indígena" que se inicia a mediados de los ochenta es su contribución a la construcción social e histórica de la aboriginalidad en Argentina. El derecho auspicia una construcción de la alteridad atravesada por la especificidad de la raza o la etnia (Briones, 1998; 2004), que como novedad, habilita el ingreso del respeto de la diversidad en el sentido común global. A diferencia de los tratamientos previos de la cuestión en los que el Estado "asimilaba" o "integraba" a sus poblaciones autóctonas al precio de exigirles una nacionalización que los homogenizaba o e invisibilizada; la nueva legislación promovió, al menos formalmente, el reconocimiento de una ciudadanía indígena diferenciada.

Ahora bien, ¿̇de qué tipo de sujeto de derechos estamos hablando? Sabemos que toda legislación destinada a un grupo poblacional particular contribuye a formar su identidad, fomentando o visibilizando determinados rasgos y ocultando otros. En el caso de los pueblos indígenas esto se hizo patente una vez que el Estado argentino comenzó a exigir a los miembros de estas colectividades dar pruebas suficientes acerca de su origen y del mantenimiento de costumbres ancestrales, como requisito para reconocerlos legalmente en el Registro de Comunidades Indígenas. En tal sentido se dirigió el Art. 3 de la ley 23.302/85 que exigió en el proceso de inscripción la presentación de pruebas que acreditaran su preexistencia o reagrupamiento. ${ }^{4}$ De esta suerte, si bien las leyes promulgadas en los ochenta implicaron un avance en el reconocimiento de la diversidad cultural, la imposición de trámites legales tales como la obtención de una personería jurídica, como requisito para el goce de

\footnotetext{
${ }^{4}$ Art 3: La inscripción será solicitada haciendo constar el nombre y domicilio de la comunidad, los miembros que la integran y su actividad principal, la pautas de su organización y los datos y antecedentes que puedan servir para acreditar su preexistencia o reagrupamiento y los demás elementos que requiera la autoridad de aplicación. En base a ello, ésta otorgará o rechazará la inscripción, la que podrá cancelarse cuando desaparezcan las condiciones que la determinaron.
} 
los derechos anunciados, obligó al acomodamiento forzado de los indígenas a las condiciones de la sociedad dominante.

Como consecuencia de esta desintonía, el derecho positivo se enfrentó a enormes contradicciones en el momento de legislar para los indígenas. Tal es el caso de los derechos colectivos. En la ley 23.302 de 1985 se optó por nomenclar como sujeto colectivo a las "comunidades" ignorando que tal definición era ajena al modo de organización política de los indígenas, regida más bien por la noción de Pueblos. El art. 2, entendió como comunidades indígenas «a los conjuntos de familias que se reconozcan como tales por el hecho de descender de poblaciones que habitaban el territorio nacional en la época de la conquista o colonización e indígenas o indios a los miembros de dicha comunidad». Con base en esta definición, el criterio de identificación del sujeto indígena previsto inicialmente fue carácter legal- administrativo: serían considerados indígenas quienes hubiesen sido identificados o definidos como tales por alguna autoridad del Estado. En este caso particular, por parte del Instituto Nacional de Asuntos Indígenas (INAI) creado bajo la égida del Ministerio de Salud y Acción Social.

Otro hiato se produjo en torno al tipo de legislación que debía regular las relaciones entre los indígenas y el Estado. En la ley del año 85, el marco normativo de estas relaciones fue el de «las leyes de cooperativas, mutualidades u otras formas de asociación contempladas en la legislación vigente» (art. 4); una disposición acorde con el espíritu de una política asistencialista más preocupada por elaborar e implementar planes de adjudicación y explotación de las tierras, de educación y de salud hacia esta población, considerada vulnerable, que por incentivar el diálogo intercultural.

Un paso importante hacia un nuevo paradigma de reconocimiento de la diversidad se produjo con la reforma constitucional de 1994 en la que se avanzó hacia la reivindicación de una ciudadanía indígena diferenciada a partir del otorgamiento de derechos especiales para estos Pueblos (Briones, 2004). El artículo 75 de la nueva carta, reconoció la preexistencia étnica y cultural de los pueblos indígenas argentinos y garantizó el respeto a su identidad y el derecho a una educación bilingüe e intercultural. Además, reconoció la personería jurídica de las comunidades indígenas y la posesión y propiedad comunitarias de las tierras ocupadas tradicionalmente. Finalmente, aseguró su participación en la gestión referida a sus recursos naturales y a los demás intereses que los afectan de manera concurrentemente con las Provincias.

La visibilización de la heterogeneidad cultural argentina habilitada por la nueva constitución, supuso la apertura en los relatos nacionales para incluir el componente originario. El reconocimiento de la preexistencia étnica y cultural desplazó a los indígenas de su condición de (ab)orígenes, para recategorizarlos como originarios, al tiempo que su identificación como Pueblos los situó dentro de sus propios cánones de organización. Se trató de un avance importante en el objetivo de resarcir la opresión histórica sufrida por los indígenas y promover la igualdad de trato en el respeto de las diferencias. 
El logro constitucional estuvo vinculado con dos procesos. Por un lado, la incorporación directa y expresa de numerosos tratados internacionales, algunas veces en correspondencia y otras en superposición y disidencia con los marcos jurídicos e institucionales preexistentes. Vale recordar que la aprobación de normativas internacionales ${ }^{5}$ fue además el producto de numerosas movilizaciones y demandas indígenas a escala planetaria, que hicieron de la visibilización del factor étnico un nuevo articulador de las luchas políticas en las décadas del ochenta y noventa.

Por otra parte, las transformaciones implicadas por los procesos de la fase flexible de acumulación capitalista bajo el esquema de la globalización y la gubernamentalidad neoliberal (Briones, 2007). Desde la década del setenta asistimos a un proceso de reetnización, refuncionalización y reinvención de las identidades indígenas y afrodescendientes, en una coyuntura que hizo de su despliegue una cuestión estratégica, en tanto mejoraba la estructura de oportunidades políticas de los participantes en relación con otros modos de articulación de demandas (como la de los trabajadores o los campesinos). Como han señalado Murillo y Seoane (2011), las luchas por la identidad, en general, y por la etnicidad en particular, tendieron a desplazar las reivindicaciones en términos de clase o ideología, consideradas ahora caducas, invisibilizando las contradicciones del modelo capitalista y reconduciendo la energía de las luchas al ámbito de la cultura. ${ }^{6}$ Es en este proceso de transición que las reivindicaciones indígenas encuentran un terreno fértil para desplegarse.

En el Estado neoliberal, la cultura y la etnicidad son las dimensiones que los indígenas tienen a la mano y ponen en la mesa para negociar políticamente y desplegar su "otredad" estratégicamente. En sintonía con dicha orientación, la política indígena promovida por los gobiernos democráticos de los años noventa se caracterizó por un cambio en el discurso hacia la multiculturalidad y la participación de los propios indígenas en el aparato estatal (Lenton y Lorenzetti, 2007).

Estas acciones coincidieron a nivel internacional con el nuevo rol que asumieron las agencias de desarrollo de los organismos multilaterales en el financiamiento de los "costos sociales" del modelo económico, las cuales vieron en el discurso multicultural una estrategia para canalizar los conflictos étnicos recrudecidos en el último período. Los procesos impulsados desde la nueva economía global provocaron un reordenamiento de los agentes involucrados en las políticas de desarrollo mundial promoviendo un proceso de neoliberalización de lo social, principalmente a través del financiamiento extranjero proveído por organismos como el Banco Mundial y el Banco Interamericano de Desarrollo. Ambas instituciones reorientaron sus acciones desde fines de los ochenta

\footnotetext{
${ }^{5}$ Tales el Convenio 169 de la OIT en 1989, la Declaración Universal de los Derechos Indígenas de las Naciones Unidas en 1994, el año de inicio del decenio de los Pueblos Indígenas (PIs) que terminara en 2004, la Declaración Americana de la OEA, entre otros.

${ }^{6}$ Los autores destacan bien este cambio de foco: «de una sociedad basada en la producción cuyos conflictos tienen que ver con la disputa por los bienes económicos, a una donde lo que se discute es la distribución de los bienes culturales y el respeto de la diversidad» (Murillo y Seoane, 2012: 144).
} 
hacia la denominada esfera de la "inversión social" cuyos objetivos, perfilados según las teorías del capital humano, se instituyeron como nuevo paradigma para enfrentar los problemas del desarrollo y la exclusión (Banco Mundial 1994; 1996).

Los organismos financieros internacionales profundizaron aún más el fenómeno de la privatización del desarrollo (Breton 2003), incorporando de manera novedosa lo étnico a su campo de intervención. Las nuevas exigencias del mercado de menos constricciones y más aperturas a nivel global, forzaron a convertir las luchas por el reconocimiento en políticas capaces de reimaginar las relaciones entre poblaciones indígenas, Estado y mercado, especialmente en aquellos territorios ubicados en lugares estratégicos para la actividad económica de las transnacionales. Esta forma de integración de la problemática indígena al discurso multicultural, se manifestó en la génesis y construcción de diversos campos de poder y saber en la política pública, ahora caracterizada por la incorporación de sectores de las propias elites indígenas en las etapas de implementación, por la reestructuración del discurso etno-político a través de formas más sofisticadas y tecnocráticas, y por la creación de una base de legitimación en un nuevo sistema de autorización y experticia comandado por ONG’s. Esta elite de expertos, con los recursos económicos y técnicos proveídos por los programas de los institutos financieros internacionales, abrió de manera estratégica campos desconocidos para la intervención del Estado, constituyéndose en sus principales facilitadores.

Con el advenimiento de las crisis económicas y financieras (mexicana, brasilera, argentina, ecuatoriana y boliviana entre otras) el agotamiento del modelo neoliberal se hizo manifiesto, obligando a un replanteamiento de la estrategia económica en la que la cuestión del desarrollo resurgió con nueva impronta. Desde la CEPAL se impulsó una "estrategia mixta" de desarrollo que apostó al aumento de la producción industrial con un énfasis marcado en el modelo exportador de manufacturas que desjerarquizó la producción de bienes de capital. La consolidación de este modelo de desarrollo coincidió con el aumento extraordinario del precio de las materias primas a nivel mundial, apuntalando una matriz productiva basada en la sobreexplotación de recursos naturales y en la expansión de las fronteras hacia territorios antes considerados como improductivos (PNUD, 2013). ${ }^{7}$ Una lectura superficial suele sugerir que la llegada de los gobiernos progresistas en América Latina implicó el abandono del reduccionismo neoliberal y el avance hacia el neodesarrollismo, perdiendo de vista que los nuevos proyectos de desarrollo nacional en la región se construyen sobre las bases creadas por el neoliberalismo. Así, como han observado Svampa (2011) y López y Vértiz (2012), el carácter transnacional del capital que

\footnotetext{
${ }^{7}$ Harvey (2008) ha señalado de qué manera la perpetua necesidad de encontrar sectores rentables para la producción y absorción de capital excedente conforma la política del capitalismo y enfrenta al capitalista con diversas barreras a la expansión continua y libre de inconvenientes. El imperativo capitalista de descubrir nuevos medios de producción en general y nuevos recursos natu rales en particular presiona de modo creciente el entorno natural a la hora de obtener las materias primas necesarias y absorber los residuos inevitables. De ahí que los capitalistas requieran descubrir nuevas áreas de extracción de recursos naturales, tarea que será encomendada a las empresas imperialistas y neocoloniales.
} 
hegemoniza el proceso de acumulación en la mayoría de los países de la región y la nueva dependencia asociada a la producción de commodities para la exportación, son sólo algunos de los factores que muestran la íntima articulación de los proyectos de desarrollo a escala nacional con las necesidades de la acumulación global extractivo-rentista.

Las políticas de la diversidad cultural emergen asi en un momento histórico en el que, como señalan Lander (2012), el capitalismo requiere la incorporación de nuevos territorios, la explotación de nuevos bienes comunes, la apropiación del conocimiento de Otros y la manipulación de los códigos de la vida y de la materia, como condición de reproducción de sus patrones de acumulación. Y he aquí la paradoja descrita por el mismo autor: en tiempos en los que «la humanidad tiene mayor urgencia de la diversidad y multiplicidad de culturas, formas de conocer, pensar, formas de vivir dentro del conjunto de las redes de la vida (como condición de posibilidad para responder a esta crisis civilizatoria), pueblos y culturas indígenas y campesinas del todo el planeta están siendo amenazadas por el avance inexorable de la lógica del proceso de acumulación por desposesión» (ibíd.).

Contra los efectos del extractivismo neodesarrollista, las luchas sociales en la región latinoamericana asisten a lo que Svampa (2011) denomina "un giro eco-territorial", fenómeno por el cual parece perfilarse un lenguaje común de valoración sobre la territorialidad, que da cuenta del cruce innovador entre la matriz indígenocomunitaria y el discurso ambientalista. Las ahora llamadas "luchas socioambientales" se rearticulan en torno a la defensa de la tierra y el territorio, multiplicando tanto las resistencias campesino- indígenas como aquellas provenientes de los movimientos ecologistas (Seonane y Taddei 2010).

En el mismo periodo, los gobiernos argentinos operaron un relanzamiento de las políticas de visibilización de los pueblos indígenas a partir de diversos dispositivos. En primer lugar los censos de población. El primero de ellos, realizado en el año 2000, incluyó la identidad indígena dentro de las variables de medición a partir del criterio del auto-reconocimiento. En la misma línea, la Encuesta Complementaria de Pueblos Indígenas (ECPI) realizada entre 2004 y 2005, respetó la declaración de las personas entrevistadas combinando dos criterios: la auto identificación o auto-reconocimiento de la pertenencia a un pueblo indígena y la ascendencia indígena en primera generación. La ECPI estimó que para aquel entonces había en el país 600.329 personas que se reconocían pertenecientes y/o descendientes en primera generación de pueblos indígenas (población indígena) (INDEC 2005). Por su parte, el Censo Nacional de Población de 2010 mostró un incremento significativo de la población auto-reconocida como indígena elevando la cifra a 955.032 personas, es decir, el 2,38 por ciento del total de la población argentina (INDEC 2012). Vale notar que el propio Informe censal del INDEC aclara que «las categorías conceptuales utilizadas por el censo no refleja la cosmovisión indígena en su relación con la tierra» (ibíd.) que prioriza la propiedad comunitaria, hecho que refleja la distancia que media aún 
entre los dispositivos estatales y el imperativo intercultural.

En segundo lugar, el sistema educativo, a partir de la puesta en marcha del Programa Nacional de Educación Intercultural Bilingüe (PNEIB) en el año 2004 y de la incorporación de la educación para los pueblos originarios en la Ley Nacional de Educación N 26.206 de 2006. Además de establecer la responsabilidad del Estado sobre la educación entendida como un bien público y un derecho humano personal y social, la nueva Ley define la Educación Intercultural Bilingüe como una modalidad del sistema educativo de los niveles de Educación Inicial, Primaria y Secundaria que garantiza el derecho constitucional de los pueblos indígenas a recibir una educación que contribuya a preservar y fortalecer sus pautas culturales, su lengua, su cosmovisión e identidad étnica; a desempeñarse activamente en un mundo multicultural y a mejorar su calidad de vida. Además, asume como misión la promoción de un diálogo de conocimientos y valores entre los pueblos indígenas y poblaciones étnica, lingüística y culturalmente diferentes, propiciando el reconocimiento y el respeto de las diferencias (art. 52, Ley 26.206).

Finalmente asistimos al surgimiento de diversos instrumentos jurídicos y administrativos que, al menos formalmente, han promovido la visibilización y participación de los indígenas. Internacionalmente, el hito principal ha sido la Declaración Universal de Derechos de los Pueblos Indígenas promulgada por la ONU en 2007; mientras que en el ámbito nacional se destacan la ley 26.160 de Emergencia de la Propiedad Comunitaria, sancionada en 2006, y la ley № 26.522 de Servicios de Comunicación Audiovisual, aprobada en 2009.

Buena parte de los motivos que concurren en la promulgación de la ley 26210 están vinculados con los conflictos derivados de la actividad extractivista en territorios indígenas. Según cifras de la ONG First Peoples Worldwide (2013) el 39 por ciento de los yacimientos en explotación de hidrocarburos en Argentina está en territorios indígenas y casi la mitad (46 por ciento) de las reservas comprobadas de petróleo y gas se ubica en zonas ocupadas por las comunidades originarias. ${ }^{8}$ El nuevo corpus normativo declaró por cuatro años la emergencia en materia de posesión y propiedad de las tierras ocupadas tradicionalmente por las comunidades indígenas con personería jurídica inscripta en el Registro Nacional de Comunidades Indígenas o el organismo provincial competente. La declaración de emergencia corrió en paralelo con la suspensión de las sentencias, actos procesales o administrativos dirigidos al desalojo o desocupación de las tierras.

El principal problema en la aplicación de la ley de emergencia radica en las dificultades para completar en tiempo y forma el relevamiento de la situación dominial de las tierras ocupadas por las comunidades indígenas,

\footnotetext{
${ }^{8}$ Los cinco casos de Argentina citados en el estudio están en la cuenca neuquina. La petrolera EOG Resources opera en el norte de la provincia, en la formación Vaca Muerta. También está presente la petrolera WPX Energy, con participación mayoritaria en Apco Oil (en Argentina opera la petrolera Entre Lomas), con extracción en Neuquén y Río Negro. Por su parte, la petrolera Apache, mantiene conflictos con las comunidades mapuches Gelay Ko y Winkul Newen, en las afueras de Zapala, y donde la empresa no cuenta con consentimiento de las comunidades. También está presente la poderosa ExxonMobil, que opera en la formación Vaca Muerta junto a YPF, Petrobras, Pan American Energy y la provincial GyP (Gas y Petróleo de Neuquén) cuenta con concesiones en Rincón de la Sauces y Añelo.
} 
hecho que ha retrasado el registro nacional y la propia obtención de las personerías jurídicas por parte de las comunidades. Según un informe de ENDEPA (2013), a seis años de sancionada la ley 26,210, sólo se había finalizado el censo catastral del 12,5\% de las comunidades originarias. La renuencia de los gobiernos provinciales y de los poderes locales a colaborar con las tareas de relevamiento, sumada al carácter no vinculante de los registros realizados por el INAI han restado eficacia al instrumento. ${ }^{9}$

Las fallas en la implementación de los dispositivos orientados a la censalización y titulación de los territorios indígenas, en tiempos del avance sostenido de la matriz extractivista, explican el sentido de las demandas que articulan hoy por hoy la lucha de los Pueblos Originarios. El Bicentenario de la Patria, en mayo de 2010, fue la oportunidad para hacer visible el giro eco- territorial. La llegada a Buenos Aires de la Marcha de los Pueblos Originarios "Caminando por la Verdad, hacia un Estado Plurinacional” proveniente de distintos puntos del país, mostró las novedades de la agenda indígena: la afirmación de la Argentina como una nación plurinacional y Pluricultural; la exigencia de una reparación histórica de los pueblos indígenas en lo que hace a su situación territorial, económica y educativo-cultural; y el pedido de reparación de la Pachamama (Página 12 2010). El documento dirigido por los participantes de la "Marcha" a la Presidenta Cristina Fernández de Kirchner, puso de presente las tensiones entre el reconocimiento formal de los derechos de los Pueblos indígenas y la lógica del desarrollo económico:

El Bicentenario debe ser la oportunidad histórica para generar el acto de reivindicación que las naciones originarias esperan en el silencio de sus montes, cordilleras, estepas, valles y montañas. Un silencio que ha sido interrumpido por el tronar de motosierras que todo desmonta, el rugido de topadoras y explosivos de las mineras que todo lo vuelan, el ingreso de petroleras que todo lo envenenan, la penetración de iglesias y sectas que todo lo convierten, partidos políticos y ofertas electorales que quiebran toda la unidad comunitaria (Marcha de los pueblos originarios 2010)

A diferencia de lo sucedido con el "Malón de Paz", los representantes de los Pueblos Originarios fueron recibidos en la Casa Rosada por la Presidenta, recibiendo de su parte el compromiso para que «aquellos que quieren seguir conservando su tradición, su lengua, lo que le enseñó su abuela y su bisabuela, como recién relataba alguien aquí, es también un derecho que debe ser respetado, no solamente porque lo diga la Constitución, sino, en definitiva, porque es la obligación de todo ser humano, respetar al otro lo que quiere ser, su historia y su identidad» (Fernández de Kirchner, 2010). El cambio respecto del paradigma asimilacionista es evidente. Ahora bien, ¿estamos en condiciones de afirmar que transitamos hacia un paradigma intercultural?

\footnotetext{
${ }^{9}$ Según revela el análisis de ENDEPA (2013: 19), «la actividad del I.N.A.I. es menor allí en donde es alta la presencia indígena en el escenario provincial y son mayores los conflictos suscitados por las resistencias a la aplicación de los derechos indígenas por parte de los gobiernos provinciales o los terratenientes. Es decir, en las provincias en donde el relevamiento es más urgente con el fin de proteger derechos en riesgo es precisamente en donde mayores deficiencias y demoras denota la acción del I.N.A.I.»
} vol.08, n. 03, Rio de Janeiro, 2015.pp. 1393-1420 


\section{EL NUEVO CÓDIGO CIVIL}

A mediados de 2012, una Comisión de juristas encabezada por Ricardo Lorenzetti se lanzó a la tarea de reformar y unificar los códigos civil y comercial. En contraposición al código vigente, basado en una división tajante entre el derecho público y el privado, el nuevo código se orientó a «receptar la constitucionalización del derecho privado, y establecer una comunidad de principios entre la Constitución, el derecho público y el derecho privado, ampliamente reclamada por la mayoría de la doctrina jurídica argentina» (Comisión redactora 2012). Esta decisión quiso expresarse en la mayoría de campos cobijados por el derecho civil: la protección de la persona humana a través de los derechos fundamentales, los derechos de incidencia colectiva, la tutela del niño, de las personas con capacidades diferentes, de la mujer, de los consumidores, de los bienes ambientales y muchos otros aspectos; a tal punto que los juristas comisionados llegaron a definir el proyecto como «una reconstrucción de la coherencia del sistema de derechos humanos con el derecho privado» (ibíd.,).

El Título V del anteproyecto se ocupó de la Propiedad Comunitaria indígena. Se trató de un apartado compuesto por doce artículos (2028 a 2036) en los que se propuso incorporar el derecho a la posesión y propiedad comunitaria indígena dentro de los parámetros del derecho civil y comercial. Después de postergar su aprobación en 2012, el Congreso retomó la actividad en torno a la reforma en marzo de 2013 convocando a los ciudadanos interesados a presentar sus impresiones acerca del proyecto en el marco de las audiencias públicas desarrolladas en Capital Federal y las distintas provincias. Respecto de los derechos indígenas, se presentaron cerca de 24 ponencias que con distintos énfasis coincidieron en una serie de modificaciones a la propuesta de la Comisión. A continuación resumimos los principales nudos del debate:

\section{El ámbito de regulación de los derechos indígenas}

¿Es el código civil el ámbito llamado a regular las relaciones entre el Estado y los Pueblos indígenas? En la mayoría de países de América Latina donde se regularon el derecho a la tierra y el territorio tras la integración constitucional de la diversidad cultural, se promulgaron leyes especiales que dotaron al derecho indígena de especificidad y regulación propias. Así ocurrió en Nicaragua, Colombia, Venezuela, Honduras y Panamá. En Argentina, sin embargo, frente a la ausencia de una ley especial de propiedad comunitaria indígena, el código civil se presentó para algunos como una oportunidad para reglamentar los derechos preexistentes.

Así lo entendió el Encuentro Nacional de Organizaciones Territoriales de Pueblos Originarios (ENOTPO), una de las entidades más representativas de los pueblos indígenas, que presentó a consideración de la Comisión Redactora un documento consensuado entre más de 40 organizaciones que representan a 27 pueblos y más de mil comunidades en todo el país. El texto se divide en ocho ejes y propone modificar una 
veintena de artículos del nuevo Código Civil y Comercial. El primer punto a destacar es la aceptación del ámbito de la reforma y unificación del código civil y comercial como locus para el despliegue de la política indígena. Para los Pueblos nucleados en ENOTPO, se trata de una oportunidad histórica para «distinguir al Código Civil de Vélez Sarsfield como una sofisticada y fina herramienta de negación de la diversidad cultural, de materialización simbólica del triunfo de un sistema opresor de ideas centrados en el Individuo y la Propiedad Privada» $\mathrm{y}$ «reparar y restituir derechos a los miles de anónimos partícipes de la liberación de los Pueblos» (ENOTPO 2013: 3). La reforma es necesaria «porque es un código de 140 años hecho a puertas cerradas, pensado desde la discriminación y con un pensamiento individualista, el pensamiento de los que gobernaban: Mitre, Sarmiento y Roca» (Página 122013 d) y ya es tiempo de romper con el paradigma individualista del derecho occidental de esencia greco-romana, e incorporar pautas propias de los Pueblos Originarios, preparando el camino hacia un nuevo paradigma basado en la interculturalidad y la complementariedad.

La postura de ENOTPO guarda relación con el llamado que hiciera el Relator Especial de Naciones Unidas sobre los Derechos de los Pueblos Indígenas, James Anaya, en su visita al país a finales del 2011, donde recomendó al estado nacional la adecuación de su sistema normativo a los estándares del derecho internacional: «Se debe actualizar, en la medida necesaria, la normativa legal, incluyendo el Código Civil, el Código Penal, el Código Minero y otra legislación nacional y provincial relevantes, para que no sea contradictoria con lo establecido por la Constitución Nacional, la legislación federal o los estándares internacionales en materia de pueblos indígenas. En todo caso, las leyes vigentes deben ser interpretadas y aplicadas de conformidad con los derechos de los pueblos indígenas reconocidos» (Citado por Rodríguez Duch 2012).

Para el INAI (2012), la iniciativa de incorporar determinados derechos indígenas en el Código Civil es una consecuencia congruente y necesaria de un camino transitado por este Gobierno Nacional en la instrumentación efectiva de derechos cuyo valor sustancial radica en que se trata de un Código de fondo con supremacía sobre las legislaciones provinciales. Se trata de una iniciativa que no sólo no desjerarquiza los derechos de raigambre constitucional, sino que los ubica en un plano de operatividad y obligatoriedad para las interpretaciones jurisprudenciales y las políticas públicas provinciales. En este sentido aporta al ordenamiento de la complejidad interjurisdiccional y a la solución de las controversias alrededor de las facultades concurrentes entre el Estado Nacional y los Estados provinciales.

A contramano de la postura que busca conciliar derecho civil y derechos indígenas, diferentes organizaciones sociales ${ }^{10}$, desaconsejaron la incorporación del derecho a la propiedad comunitaria indígena en el nuevo Código (Página 12 2012). En su concepto, los derechos de los pueblos indígenas, son derechos nuevos,

\footnotetext{
${ }^{10}$ Entre otras, el Centro de Estudios Legales y Sociales (Cels), Madres de Plaza de Mayo Línea Fundadora, la Asamblea Permanente de Derechos Humanos (APDH), el Servicio de Paz y Justicia (Serpaj), la Asociación de Abogados de Derecho Indígena (AADI), el Equipo Nacional de Pastoral Aborigen (Endepa) y el Observatorio de Derechos Humanos de Pueblos Indígenas (Odhpi).
} vol.08, nº.03, Rio de Janeiro, 2015.pp. 1393-1420 1406 
que tienen una naturaleza única, se desarrollan en el marco del derecho internacional de los derechos humanos y del derecho constitucional y parten de una cosmovisión que nada tiene que ver con la tradición y regulación de las relaciones propias de occidente que hallaron un espacio central para desarrollarse en los códigos civiles romanistas. En tal sentido, los derechos humanos de los pueblos indígenas exigen la incorporación de mecanismos legales adecuados que reflejen y respeten su identidad cultural, en los que el territorio y los derechos territoriales adquieren un lugar de trascendencia (CELS et al 2012:3).

En el mismo sentido se manifestaron los dirigentes originarios que componen el Consejo Plurinacional Indígena ${ }^{11}$ : «más allá de la propaganda sobre la inclusión de nuestros derechos y del respeto a la diversidad cultural en el nuevo CC, lo concreto es que atenta contra la base de nuestro desarrollo cultural que son nuestros territorios y derechos fundamentales que no fueron tomados en cuenta al momento de pretender incluirnos» (Consejo Plurinacional 2012). El Consejo Plurinacional puso en alerta y movilización a los Pueblos Originarios por la no inclusión de los derechos a la consulta, al consentimiento previo e informado y a gozar de una personería jurídica pública, dentro del texto a aprobar. Veamos estas últimas cuestiones con mayor detenimiento.

\section{Informar no es consultar}

Para el Consejo Plurinacional, así como para las ONG's encabezadas por el CELS, uno de los puntos más críticos del anteproyecto presentado por Lorenzetti fue su carácter inconsulto. Tanto la Constitución Nacional, como los instrumentos internacionales suscritos por la Argentina ${ }^{12}$ obligan al Estado a consultar a los Pueblos Indígenas a través de sus instituciones representativas, cuando se legisla sobre aspectos que puedan afectar los intereses del conjunto de pueblos y culturas. Según el Consejo Plurinacional (2012), «la inclusión del título V en el anteproyecto de ley, no se consultó ni siquiera al Consejo de Participación Indígena (CPI), creado en el marco del mismo Instituto Nacional de Asuntos Indígenas, INAI». Además, denunció «que no se le brindo el tiempo necesario para el debate y peor aún, se fraguó un documento que fue presentado a esta Bicameral a nombre de CPI, sin la autorización de sus miembros, incluso de quienes aparecen firmando esa ponencia.»

Lo anterior no implica que no haya existido ninguna instancia de participación. Como señalamos en párrafos anteriores, la Comisión Bicameral convocó decenas de audiencias públicas en el país para la discusión del anteproyecto de reforma. El problema radica en que estas audiencias no tuvieron un efecto vinculante, por lo que se eludió la obligación estatal de aplicar la consulta como mecanismo para obtener el Libre Consentimiento Fundamentado Previo de las comunidades de los Pueblos Originario. Por tal razón -sostienen los ponentes del

\footnotetext{
${ }^{11}$ El Consejo Plurinacional Indígena es una instancia política representada por las organizaciones de los Pueblos Originarios de los diversos extremos del país. Se formó después de la marcha de casi 30 mil indígenas hacia Buenos Aires de los cuatro puntos de Argentina, el 20 de mayo de 2010, durante la celebración de los 200 años de la Independencia.

${ }^{12}$ Ley 24.071, Aprobación del Convenio 169 de la OIT Art. 6; Declaración Universal de los Derechos de los Pueblos Indígenas de la ONU Art. 19; Corte Interamericana de Derechos Humanos- Caso Saramaka vs. Surinam, 28 nov 2007.
} vol.08, n. 03, Rio de Janeiro, 2015.pp. 1393-1420 
CELS- para que el texto de determinada norma resulte válido es necesario que se generen los mecanismos de consulta con los pueblos indígenas, mediante procedimientos adecuados y a través de sus instituciones representaciones, respetando los estándares internacionales en materia de derecho a la consulta y participación vinculados, entre otros, con la realización de procedimientos de buena fe, realizados en tiempo oportuno y que tenga como fin llegar a un acuerdo o consenso, etc. (CELS et al 2012).

Previendo estas situaciones, el documento propuesto por ENOTPO (2012) refirió expresamente la incorporación del derecho de consulta y participación en relación con los territorios indígenas en el artículo 2035: «El aprovechamiento de los recursos naturales por parte del Estado o de particulares con incidencia en las tierras y territorios indígenas, está sujeto al derecho a la participación y a un proceso adecuado de consulta con los pueblos indígenas afectados, a los fines de obtener su Consentimiento Libre, Previo e Informado». En la exposición de motivos exhortó a los legisladores a seguir el criterio esgrimido por la Corte Interamericana de Derechos Humanos, según el cual el deber de consulta de surgir «desde las primeras etapas del plan de desarrollo o inversión y no únicamente cuando surja la necesidad de obtener la aprobación de una comunidad» (Ibíd.,).

El anteproyecto de Reforma se refiere a la consulta en términos que distan de lo pautado en la legislación internacional. Así, el artículo 2035: reza «El aprovechamiento de los recursos naturales por parte del Estado o de particulares con incidencia en los hábitats indígenas está sujeto a previa información y consulta a las comunidades indígenas respectiva» (Comisión redactora 2011). Cabe notar que la información no es equivalente a la consulta para el consentimiento libre previo e informado reconocido en la Declaración Universal de los Derechos de los Pueblos Indígenas de Naciones Unidas. Mientras el primero es un trámite administrativo no vinculante, el segundo implica la manifestación colectiva de los pueblos originarios a decidir acerca de la utilización, administración y conservación de los bienes y recursos naturales en territorio indígena, haciendo necesaria la implementación de un proceso de participación respetuoso de los valores, tiempos y características culturales de los Pueblos Indígenas.

\section{Personería Jurídica: ¿Y ahora de qué nos disfrazamos?}

La Constitución Nacional reconoce a los Pueblos indígenas como preexistentes al Estado nacional, y a su personería jurídica como propia del derecho público no estatal, en el entendido de que sólo una personería tal puede garantizar la libertad de estos pueblos en relación con su cultura y territorios. En el espíritu de la Carta, se halla así la comprensión de los Pueblos como estructuras institucionales de carácter autónomo tanto político, como económico cultural y social.

El artículo 148 del proyecto de reforma del CC modifica el carácter de persona jurídica de las Comunidades Indígenas enmarcándolas en el derecho privado. Esto significa que las sitúa al mismo nivel que las 
asociaciones civiles, las fundaciones, las sociedades comerciales o las cooperativas negando la realidad jurídica previa y desconociendo el carácter declarativo de las resoluciones de inscripción, toda vez que, al introducir a aquellas dentro de la categoría de personas de derecho privado, las equipara a las otras personas jurídicas que constituye el Estado.

A este respecto, las distintas organizaciones indígenas han sido enfáticas al señalar que sus normas y sistemas de justicia, sus criterios de convivencia o de administración de su economía, educación y salud, no puede quedar reducidos y controlados en una "personería jurídica de derecho privado", ya que esto lesiona gravemente los principios de pre- existencia y autonomía al habilitar la intervención del Estado y sus organismos de control en la vida interna y en los procesos organizativos de las comunidades (Consejo Plurinacional, 2012).

Lo que subyace en el fondo de la cuestión es cuáles son los límites permitidos a la intervención estatal en aras de defender los derechos indígenas. Por un lado, las personerías jurídicas operan como instrumentos de reconocimiento que permiten a las comunidades reclamar sus derechos ante las instancias estatales (particularmente ante el poder judicial en procesos de desalojo); pero, al mismo tiempo, dichas personerías se configuran como órganos de intervención y control que amenazan la autonomía de las comunidades indígenas.

Bidaseca et al (2011) ha hecho una interesante reflexión al respecto, señalando cómo «la promoción del registro de personerías jurídicas es un dispositivo jurídico-burocráctico privilegiado para ordenar la asignación de estos sujetos emergentes como partes del orden social». La tensión entre el reconocimiento y la autonomía atraviesa la dinámica de las propias comunidades indígenas. Sin medidas efectivas de protección a la posesión y propiedad de las tierras "que tradicionalmente ocupan", la indefensión jurídica de las comunidades se profundiza porque a la par que el Estado se confiesa impotente para evitar la invasión de las tierras indígenas y la destrucción de sus recursos naturales, alienta una política de inversiones destinada a organismos multinacionales, empresas nacionales y extranjeras para la instalación en las mismas de emprendimientos productivos de diversa índole.

Tanto el Estado Nacional como algunos Estados Provinciales vienen incumpliendo de manera sistemática el deber de reconocimiento y registro de la personalidad jurídica de las Comunidades que así lo solicitan. Ambas esferas de poder vienen evadiendo esta obligación pese a que el mandato constitucional es claro (art. 75/17) y la legislación nacional ha reglamentado la posibilidad de inscripción (ley nacional № 23.302, decreto N¹55/89 y resolución 481 1/96 Secretaría de Desarrollo Social de la Nación).

Varias son las razones que han sustentado la negativa a reconocer comunidades. De parte de los Estados provinciales, se ha argumentado que el Estado Nacional carece de atribuciones en materia de registración de comunidades indígenas. Así lo ha sostenido, por ejemplo, la Provincia del Neuquén, aduciendo que tiene facultades propias excluyentes de las del Gobierno Federal, reservadas constitucionalmente y que el reconocimiento de comunidades indígenas se encuentra dentro de las atribuciones del "poder de policía" de los 
Estados Provinciales. Esto ha llevado al gobierno neuquino a denunciar la inconstitucionalidad de la ley nacional 23.302, de política indígena, y a iniciar una demanda contra el INAI, solicitando a la Corte Suprema de Justicia de la Nación que anule seis personerías jurídicas reconocidas por el Registro Nacional de Comunidades Indígenas RENACI- (ODHPI 2014).

Por otra parte, erosionando el principio de preexistencia, se suele considerar que la personalidad de las comunidades indígenas depende de la realización de un acto administrativo y que para llegar al mismo, el Estado debe corroborar la identidad indígena y decidir si hay o no comunidad para así otorgar personalidad jurídica. Bajo este supuesto, las autoridades estatales encarnadas en el INAI o en las Direcciones Provinciales de Registro, estarían facultadas a exigir a las comunidades que soliciten inscripción, la demostración de innumerables requisitos que den certeza del origen indígena. ${ }^{13}$

Frente a este "conflicto de interpretaciones", el fallo de inconstitucionalidad de un decreto del Poder Ejecuto de la Provincia de Neuquén en el año 2002, por parte de la Corte Suprema de Justicia de la Nación (en sentencia dictada el 10 de diciembre de 2013, en el marco de una causa promovida por la Confederación Mapuche) sentó un precedente de suma importancia. El decreto provincial exigía el cumplimiento de una serie de formalidades no mencionadas en la ley nacional, que constituían más obstáculos para la obtención de la personería ${ }^{14}$.

La Corte Suprema aclaró en el fallo los términos de la competencia en relación al registro de comunidades indígenas; confirmó el criterio de la autoidentificación como el criterio central para el reconocimiento de la identidad indígena y, por primera vez, fijó los términos de las competencias concurrentes entre el ámbito federal y provincial. De modo inédito, reasentó la vigencia del criterio de la autoidentificación poniendo en evidencia que el decreto declarado inconstitucional, no sólo no preveía ese concepto establecido en la legislación nacional e internacional como un criterio fundamental de inscripción, sino que lo sustituía por el principio opuesto de identificación del Estado. Con enorme vehemencia, el máximo tribunal afirmó que

\footnotetext{
${ }^{13}$ Asi por ejemplo, en la rendición de informes del Jefe de Gabinete ante la Cámara de Diputados en el año 2006, ante la pregunta por el retraso en la inscripción de las personerías jurídicas de más de 130 comunidades en todo el país, el Ministerio de Desarrollo Social adujo que los motivos por los cuales estas solicitudes se encontraban en trámite eran los siguientes: «1) Solicitudes de Comunidades que no completaron la documentación requerida de acuerdo a lo establecido por la Res. 4811/96 de la ex Secretaría de Desarrollo Social de la Nación, 2) Solicitudes de Comunidades que son fraccionamientos de otras ya inscriptas, 3) Solicitudes de Comunidades que ya cuentan con personería jurídica, a nivel nacional o provincial, 4) Solicitudes que aunque completaron la documentación, expresan en su seno conflictos que obstaculizan la inscripción, 5) Solicitudes de conjuntos de familias o personas que no encuadran en la normativa que rige la materia, Ley Nacional 23.302 y Decreto Reglamentario 155/89» (Jefatura de Gabinete, 2006).

${ }^{14}$ Tales como: descripción del territorio que ocupan las comunidades, acreditación de la propiedad de los respectivos lotes (inc. a), presentación de un registro de integrantes de la comunidad anualmente actualizado (inc. b) adjunción de un documento que refleje su organización, libro de ingresos y egresos patrimoniales (inc. d), reseña histórica circunstanciada que describa el orden cronológico familiar, origen étnico cultural e histórico. Como si ello no bastara, la autoridad de aplicación podría requerir otros requisitos tales como la acreditación de identidad étnica, lengua actual, cultura propia, hábitat común y un mínimo de 10 familias, además de otros futuros requisitos que "puedan surgir del trabajo de campo" (Decreto 1184 de 2002, Poder Ejecutivo Provincia de Neuquén).
} 
«cualquier agrupación, entidad o comunidad que se cree y organice de acuerdo al derecho indígena en el marco de su convivencia colectiva, merecen ser reconocidos, registrados o inscriptos» (Corte Suprema 2013). Y esto es así dado que la autoidentificación es un criterio político, limitativo del poder estatal y vinculado a la libre determinación. Así las cosas, «optar por la posibilidad de que sea el Estado, de manera externa, quien decida quién es indígena y quién no, equivaldría a negar la facultad más básica de ejercicio de la autonomía, como lo es determinar quién es parte del grupo y quién no» (Ibid.,).

Del debate abierto por las personerías jurídicas de las comunidades indígenas hay al menos dos cosas que nos interesa destacar. Por un lado, la potencia de los instrumentos jurídico- administrativos dentro de las estrategias desplegadas por el Estado para extender y profundizar su dominio hacia áreas antes ignoradas o negadas por el sistema. El Estado no solo busca asegurar su capacidad de concentrar capital simbólico a través de las representaciones de la identidad indígena que exige como pruebas ciertas para la inscripción en el registro de comunidades. No sólo afirma y legitima el papel del derecho positivo como autoridad validadora de las experiencias interculturales, sino que somete a las comunidades indígenas a este dispositivo como único modo de reclamar derechos. De ahí que, aunque parezca paradójico, las comunidades indígenas exijan dentro de sus demandas actuales la oportuna inscripción en el RENACI y el urgente relevamiento de las tierras que ocupan.

En segundo lugar, deseamos resaltar cómo la experiencia en torno al registro de personerías jurídicas obligó a los indígenas a apropiarse y hacer jugar a su favor el saber jurídico, con miras a salvaguardar sus derechos. En este sentido encontramos de enorme interés la interpretación jurídica hecha por ENOTPO en su contrapropuesta a la Comisión Bicameral de reforma del CC:

Resulta esencial señalar que, en función de la misma noción de preexistencia que hoy reconoce la constitución a favor de los pueblos indígenas, la inscripción que realiza el Estado de las distintas comunidades no cuenta con un carácter constitutivo (...). Por tanto, el reconocimiento que el Estado realice respecto de las comunidades y organizaciones indígenas al registrar su Personería Jurídica tendrá un carácter meramente declarativo, limitándose para el caso a constatar su existencia y a inscribirlas, no debiendo involucrarse en el juzgamiento del tipo de organización que los mismos se brinden ni de sus reglas internas ( ... la técnica jurídica empleada por el Estado (...) debe ser la de una "constatación" y no la de una "concesión”, razón por la cual el reconocimiento de su existencia por parte de cualquier acto público permitirá a la Comunidad disponer de Personalidad Jurídica (ENOTPO 2012 cursivas nuestras)

\section{La propiedad comunitaria indígena. ¿De qué tipo de derecho estamos hablando?}

Lo que está en el centro del debate es la inadecuación de los principios privatistas del código civil para incorporar figuras del derecho indígena. Tengamos en cuenta que el Código Civil Argentino data de 1871, y que 
tal como lo hacían todos los Códigos de la época, el derecho de propiedad romano-germánico fue instalado como el único paradigma de la relación que debían sostener los hombres con las "cosas". Nada dijo Vélez Sarsfield respecto de algún sujeto de derecho que pudiera existir en cabeza de una comunidad originaria, toda vez que entonces se buscó extinguir o asimilar a los pueblos indígenas al resto de la sociedad europeizada. Mucho menos incursionó el autor del código en la posibilidad de legalizar algún tipo de posesión específica que permitiera hablar de "propiedad comunitaria indígena".

Más de un siglo después, en 1985, el Congreso sancionaría la ley 23.302 de política indígena en la que propondría, entre otros institutos jurídicos, la regulación de la propiedad comunitaria y la personería jurídica comunitaria, avanzando sobre las anquilosadas nociones del Código Civil, al considerar a las Comunidades indígenas como sujetos de derecho. La actual reforma estaría así ante el reto/dificultad de incluir los derechos colectivos en una normativa históricamente dedicada al derecho individual y privado.

Según el INAI (2012), la incorporación de la Propiedad Comunitaria Indígena en el Código Civil y Comercial Unificado surge como una necesidad frente a los atropellos de que son víctimas las comunidades indígenas ante la ausencia de una ley que regule la materia. El Código Civil vendría a conferir unidad y coherencia, a evitar confusiones, facilitar el conocimiento, favorecer la conformación de un espíritu nacional, pero sobre todo, a imponerse frente a las legislaciones provinciales. Las bondades de esta incorporación no pueden ser advertidas si no se dimensiona la naturaleza novedosa del nuevo código, la cual sería diametralmente diferente a la de aquel concebido por Vélez Sarsfield:

Se trata de un Nuevo Código Civil, con un nuevo enfoque y que modifica profundamente el vigente. Pondera la costumbre, asume la interculturalidad, consagra derechos de incidencia colectivos, integra derechos humanos, versa sobre derecho privado pero también sobre elementos del derecho público, incorpora una gran regulación que se dedica a los niños, aplicando la Convención de los Derechos del Niño, protección de los ancianos, regula la capacidad de las personas con enfermedades mentales, se incorporan los derechos personalísimos que hacen a la defensa de la persona, el derecho a la privacidad o la anulación de contratos riesgosos, agiliza los trámites de divorcio, tenencia de hijos y distribución de bienes, etc. y también incorpora los elementos centrales que reconoce la Constitución Nacional a las comunidades indígenas (INAI, 2012,).

Las organizaciones indígenas agrupadas en ENOTPO plantean que el territorio sea contemplado en el Código como parte de la vida indígena, abarcando tanto la tierra como el agua y los recursos naturales, además de todo su contenido ancestral y simbólico en una cosmovisión mucho más amplia que la actual, que habla en términos de tierras y bienes inmuebles rurales. Por otro lado, sugiere que la norma hable tanto de propiedad como de posesión de la tierra, tal y como reconoce la Constitución.

Quienes se oponen a la inclusión de la propiedad comunitaria indígena en el nuevo código, aducen que la posesión y la propiedad indígena tienen una naturaleza y forma muy diferentes a la posesión y propiedad del 
derecho occidental, lo cual obliga a sancionar un régimen jurídico distinto. El Derecho a la tierra y al territorio indígena se refiere a una relación jurídica entre el Estado y los particulares (en este caso, entre el Estado y los pueblos y comunidades indígenas) y no a una relación que tenga por objeto exclusivo al individuo, la facultad de servirse de una cosa o que establezca relaciones de igualdad entre sujetos privados. Por el contrario, dentro de la cosmovisión indígena, el modo de poseer un territorio se vincula con la manera en que los miembros de una comunidad o un pueblo desarrolla una relación de pertenencia con aquel espacio necesario para la conservación y transmisión de su cultura ancestral.

El Equipo Nacional de Pastoral Aborigen -ENDEPA- (2012) objetó ante la Comisión Bicameral que el proyecto incluyera a la propiedad comunitaria indígena dentro de la categoría de los derechos reales, que en el campo del derecho son clasificados a su vez como derechos patrimoniales. En su concepto, tal designación vaciaba de contenido la especial relación cultural, espiritual e identitaria que tienen los pueblos indígenas con su territorio en la medida en que el derecho de propiedad indígena de ningún modo se agota en lo patrimonial o económico, distinguiéndose totalmente de la propiedad privada. Siendo un concepto económico y patrimonial, «el derecho real implica la relación directa de un sujeto sobre un objeto, por el cual el sujeto ejerce un poder o señorío sobre la cosa. Eso significa ser titular de un derecho real como el dominio (propiedad privada» (Ibíd.). La propiedad comunitaria indígena dista profundamente de esta concepción. «Para los pueblos originarios no es que la tierra les pertenezca sino que ellos le pertenecen a la tierra. En ese sentido, el modo de ejercer la posesión "en muchos casos casi imperceptible" será también diferente al del modo occidental de ejercerlo» (Ibíd.).). Esta diferencia, según ENDEPA, es omitida en el anteproyecto de reforma.

Debate aparte mereció el tipo de figura creado para la suscripción de los derechos de propiedad. La propuesta de la Comisión redactora se refiere a la Comunidad y no a los Pueblos indígenas como obligan la Constitución nacional, el Convenio 169 y la Declaración Universal de derechos indígenas de la ONU. Según el Consejo Plurinacional indígena «la comunidad es la célula sobre la cual se organizan los pueblos indígenas; los pueblos indígenas están integrados por comunidades» (Consejo Plurinacional, 2012). Pero la garantía mínima para que la vida comunitaria pueda desarrollarse y ser viable en medio de un ambiente hostil y de permanente invasión cultural es consolidar formas de organización e identidad política como Pueblos.

\section{¿UN CÓDIGO CIVIL INTERCULTURAL?}

El 21 de noviembre de 2013 el Senado argentino aprobó con media sanción el texto final del Nuevo Código Civil y Comercial de la Nación. El nuevo corpus jurídico incorporó los derechos de las comunidades indígenas en el artículo 18: 
Derechos de las comunidades indígenas. Las comunidades indígenas reconocidas tienen derecho a la posesión y propiedad comunitaria de las tierras que tradicionalmente ocupan y de aquellas otras aptas y suficientes para el desarrollo humano según lo establezca la ley, de conformidad con lo dispuesto por el artículo 75 inciso 17 de la Constitución Nacional.

Además, modificó el carácter de la personería jurídica de las comunidades indígenas enmarcándolas en el derecho privado. En el mismo apartado, la Iglesia Católica logró conservar la personería jurídica pública no estatal. Por otra parte, el título V dedicado a la Propiedad Comunitaria Indígena fue eliminado del proyecto y el Poder Legislativo hizo anuncios respecto de una futura reglamentación de este derecho en una ley especial.

De lo escueto del texto aprobado no se sigue un impacto menor para los Pueblos Indígenas. El nuevo código resigna su comprensión jurídica a la noción de comunidades y no de Pueblos, desconociendo los cánones de su organización política y territorial. Vulnera el principio de preexistencia con la modificación de la personería jurídica de las comunidades dentro del ámbito del derecho privado. En tiempos de un flagrante enfrentamiento con los gobiernos provinciales y locales en defensa de sus territorios, los Pueblos indígenas fueron desjerarquizados y puestos al nivel de cualquier otra organización civil, pendiendo sus derechos de la obtención de una personería otorgada por el Estado. El derecho de propiedad y posesión reconocido por el nuevo código versa sobre las tierras que tradicionalmente ocupan y no sobre los territorios, con lo cual quedaron descartadas los recursos como el agua y el subsuelo y las posesiones y propiedades no rurales.

En estas condiciones, tenemos hondas dificultades para compartir el optimismo de organismos como el INAI y el propio ENOTPO en el sentido de que el Nuevo Código «recepta la pluriculturalidad y no produce disminución de derechos, sino que los reafirma y desarrolla» (INAI, 2012; ENOTPO, 2013b). Además, albergamos serias dudas de que en el corto plazo curse una nueva iniciativa legislativa que defina la cuestión de la propiedad comunitaria indígena. A diferencia de otros temas que fueron excluidos del proyecto de reforma para ser objeto de una ley especial, como fue el caso de la responsabilidad del Estado (Página 12, 2013 a) los derechos a la propiedad comunitaria indígena no han sido objeto de un proyecto de ley alternativo que haya sido ingresado a la agenda parlamentaria en los meses recientes. Así las cosas, el camino por recorrer es largo e incierto, y son difusos los elementos que permitirían concluir que esta reforma redundará en un avance sustancial en materia de derechos indígenas.

A lo largo de la discusión, vimos que las dificultades para incluir los derechos indígenas en el código civil provienen de su novedad y naturaleza específica: emergen de una visión holista, tradicional y colectivista del mundo que difícilmente puede encuadrarse en las tendencias romanistas. Al reducir al código civil la cuestión indígena, en el afán por reglamentar aquello prometido en la Constitución, el Estado argentino corre el riesgo de terminar imponiendo su verdad jurídica, alejándose del diálogo intercultural tan invocado. Por su naturaleza, y más allá de la hibridez que presuma el nuevo código, el derecho privado rechaza todo aquello que contradiga el 
sistema o los valores a los que responde: el individuo, la propiedad privada y la competencia, y en esta medida, hace que la norma deje de ser un instrumento regulador de realidades sociales para convertirse en un instrumento de dominación del más fuerte.

En nuestra lectura, si ha de buscarse un valor positivo a la experiencia de la reforma y unificación del código civil, esta debe hallarse en la amplitud y calidad del debate que desató, dando a los Pueblos Indígenas la oportunidad de mostrar el nivel de organización y movilización alcanzado en los últimos años. Merece destacarse su capacidad para vincular a las luchas étnicas a representantes de otros sectores sociales, pero también su determinación de no delegar nunca más la política indígena en otras manos. Así, al tiempo que se acompañaron del juez español Baltasar Garzón o del Nobel de Paz Pérez Esquivel, los Pueblos originarios marcaron distancia frente a las organizaciones internacionales, las Iglesias y las ONG's que desde los noventa devinieron fórmulas refinadas de la intervención y las prácticas colonialistas, reduccionistas y negadoras de los derechos indígenas: «Estos sagaces recopiladores de nuestras situaciones de conflicto [que] llenan interminables informes, elaborados con fina pluma, que luego presentan a los denominados "especialistas en temas indígenas", en grandes púlpitos y con destacada audiencia, pero que finalmente nada resuelven hacia el interior profundo de nuestros territorios» (ENOTPO, 2012).

A veinticinco años de la promulgación del Convenio 169 de la OIT, la explosión de interpretaciones en torno a los modos de concretar y efectivizar los derechos indígenas garantizados sigue patente. Mientras los organismos financieros buscan insertar a los indígenas en el circuito comercial global adjudicando valor económico a sus saberes y prácticas; ONG's de derechos humanos y sectores de la academia insisten en la necesidad de preservar y proteger su autonomía respecto del mundo del mercado y el Estado. Ambas posturas contribuyen a un paternalismo con tintes de patrimonialización y folklorización, que termina haciendo del indígena un sujeto del asistencialismo con una identidad anquilosada en sus tradiciones ancestrales. Así, al hablar en nombre de "los que no tienen voz", juristas, expertos, burócratas, académicos y defensores de derechos humanos, a veces con las mejores intenciones, desoyen los intereses divergentes y conflictivos de los Pueblos Originarios: el tipo de relación que éstos desean entablar con el Estado, con el sistema económico y con el régimen político. Ignoran que estos espacios no sólo no son ajenos a la realidad de los indígenas, sino que constituyen, de hecho, sus escenarios actuales de disputa. Más aún, estos “representantes de los sin voz" ignoran que los indígenas no quieren ser protegidos ni preservados, sino que quieren, y de hecho son, actores protagónicos de su destino. 


\title{
BETWEEN RECOGNITION AND NO CONSULTATION: INDIGENOUS RIGHTS IN THE REFORM OF ARGENTINE CIVIL AND COMMERCIAL CODE
}

\begin{abstract}
The paper traces and analyzes the inclusion of indigenous rights in the draft of reform and unification of civil and commercial code in Argentine. It is argued that this process reissues three problem knots of intercultural dialogue: the incompatibility between western and indigenous visions under the grid of positive law; the precarious incorporation of indigenous struggles in devices and institutional settings opened by the liberal State and the aporias of implementation of policies of cultural diversity in times of advancing the neoliberal model and its successor, the neo-developmentalism.
\end{abstract}

Keywords: Indigenous rights, civil and commercial code, Argentine, interculturality

\section{BIBLIOGRAFÍA}

BANCO MUNDIAL. Indigenous Peoples and Poverty in Latin America: An Empirical Analysis. Psacharopoulos, George and Patrinos, Harry A (eds) Washington, DC: The World Bank, 1994. Disponible en http://documents.worldbank.org/curated/en/1994/09/438861/indigenous-people-poverty-latin-americaempirical-analysis Consultado: 06/06/2014

Including the excluded: ethnodevelopment in Latin America. The World Bank Latin America and the Caribbean Technical Department Environment Unit, 1996. Disponible en http://documentos.bancomundial.org/curated/es/1996/07/2694959/including-excluded-ethnodevelopmentlatin-america Consultado 06/11/2013

BIDASECA, Karina et al. Dispositivos miméticos y efectos de identidad. Ensayo de una interpretación crítica sobre las personerías jurídicas y las comunidades originarias, en Bidaseca, K (coord.) Signos de la identidad. Emergencias identitarias en el límite del tiempo histórico, Buenos Aires, SB, 2011, pp. 153-167.

BRETÓN, Víctor y García, Francisco (eds). Estado, etnicidad y movimientos sociales en América Latina. Ecuador en crisis, Barcelona, Icaria, 2003.

BRIONES, Claudia. (Meta) cultura del Estado-nación y estado de la (Meta) cultura. Ponencia presentada al Seminario Internacional Uma Agenda para a Antropologia a partir da América Latina, Brasilia, 1998. Disponible en:https://docs.google.com/document/d/leGzVGyjfNdRoi6gAExgE5nwB1HSZbWn8WgrVFY_ZXY/edit? hl=es Consultado: 06/06/2014

Construcciones de Aboriginalidad en Argentina, en Bulletin de la Société Suisse des Américanistes. Ginebra. Nro. 68, 1994, pp 73-90.

(2005) Cartografias argentinas: políticas indígenas y formaciones provinciales de alteridad, Buenos Aires, Antropofagia.

BRIONES, Claudia; Cañuqueo, Lorena; Kropff, Laura; Leuman, Miguel. Escenas del multiculturalismo neoliberal. Una proyección desde el Sur, en Grimson, Alejandro (comp) Cultura y Neoliberalismo, Buenos Aires, CLACSO, 2007.

CARRASCO, Morita (ed.). Los derechos de los pueblos indígenas en Argentina, Buenos Aires, VinciGuerra vol.08, nº. 03, Rio de Janeiro, 2015. pp. 1393-1420 
Testimonios. No 30, 2000.

CELS et al. Posición de los organismos de derechos humanos y organizaciones sociales firmantes en relación con la incorporación de los derechos indígenas en el Código Civil. Ponencia presentada ante la Comisión Bicameral para la Reforma, Actualización y Unificación de los Códigos Civil y Comercial de la Nación, Buenos Aires, 21 de agosto de 2012

COMISIÓN REDACTORA DEL CÓDIGO CIVIL. Texto del Proyecto de Reforma, Actualización y Unificación de los Códigos Civil y Comercial de la Nación, 2011. Disponible en: http://www.nuevocodigocivil.com/textos-oficiales/ Consultado: 08/06/2014

Aspectos valorativos y principios preliminares del anteproyecto de código civil y comercial de la nación, 2012. Disponible en http://www.nuevocodigocivil.com/aspectos-valorativos-y-principios-preliminares-delanteproyecto-de-codigo-civil-y-comercial-de-la-nacion/ Consultado: 08/06/2014

CONSEJO PLURINACIONAL INDÍGENA. Aportes del Consejo Plurinacional al tratamiento de la propiedad Comunitaria indígena en el Código Civil. Ponencia presentada ante la Comisión Bicameral para la Reforma, Actualización y Unificación de los Códigos Civil y Comercial de la Nación, Buenos Aires, agosto de 2012.

CORTE SUPREMA DE JUSTICIA DE LA NACIÓN, Fallo C. 1324. XLVII. Confederación Indígena de Neuquén contra Provincia del Neuquén solicitando acción de inconstitucionalidad, Buenos Aires, 10 de diciembre de 2013.

ENDEPA. Postura de Endepa ante la reforma del Código Civil, Ponencia presentada ante la Comisión Bicameral para la Reforma, Actualización y Unificación de los Códigos Civil y Comercial de la Nación, Formosa, agosto de 2012.

Nueva advertencia sobre la inejecución de la ley 26.160. La brecha entre las declaraciones y la realidad en materia de derechos territoriales indígenas, 2013. Disponible: http://odhpi.org/2013/08/territorios-indigenasla-deuda-eterna/ Consultado: 04/06/2014

Posicionamiento Jurídico del Encuentro Nacional de Organizaciones Territoriales de Pueblos Originarios frente la Reforma, Actualización y Unificación de los Códigos Civil y Comercial de la Nación, 2012. Disponible en http://odhpi.org/codigo-civil/ Consultado:08/06/2014

Código Civil Intercultural. Se incorpora el Derecho indígena en el código civil, 2013. Disponible en http://enotpo.blogspot.com.ar/2013/11/codigo-civil-pluricultural.html Consultado:08/06/2014

KIRCHNER, Fernández de Palabras de la Presidenta de la Nación Argentina ante representantes de los pueblos originarios, en el salón de las mujeres argentinas de la Casa de gobierno, mayo 20 de 2010, disponible en http://www.casarosada.gov.ar/sitios-de-gobierno/planes-de-gobierno/3807C Consultado: 21/11/2013

FIRST PEOPLES WORLDWIDES FPW. Indigenous Rights Risk Report for the Extractive Industry (U.S.), 2013. Disponible en: http:/ /firstpeoples.org/indigenous-rights-risk-report Consultado: 08/06/2014

GORDILLO, Gastón y Hirsch Claudia. La presencia ausente: invisibilizaciones, políticas estatales y emergencias indígenas en la argentina, en Gordillo, Gastón y Hirsch Claudia (comps.) Movilizaciones indígenas e identidades en disputa en la Argentina, Buenos Aires, La Crujía, 2010.

HALPERÍN- DONGHI, Tulio. Una nación para el desierto argentino, Buenos Aires, Centro Editor de América Latina, 1992. 
HARVEY, David. El derecho a la ciudad, New Left Review No 53 Nov- Dic, 2008. Disponible en http://newleftreview.es/53 Consultado: 08/06/2014

INSTITUTO NACIONAL DE ASUNTOS INDIGENAS INAI. Derechos indígenas y proyecto de Código civil y comercial unificado. Presentación ante la Comisión Bicameral para la Reforma y Unificación del Código civil y Comercial, Buenos Aires, 2012. Disponible en http://odhpi.org/codigo-civil/ Consultado: 08/06/2014

INSTITUTO NACIONAL DE ESTADISTICAS INDEC. Encuesta Complementaria de Pueblos Indígenas, 2005. Disponible en http://www.indec.mecon.ar/webcenso/ecpi/index_ecpias Consultado: 04/06/2014

Base de Datos del Censo Nacional de Población, 2012. disponible en http://200.51.91.245/argbin/RpWebEngine.exe/PortalAction?\&MODE=MAIN\&BASE=CPV2010B\&MAIN =WebServerMain.inl Consultado: 04/06/2014

LANDER, Edgardo. ¿Un nuevo periodo histórico? Crisis civilizatoria, límites del planeta, desigualdad, asaltos a la democracia, estado de guerra permanente y pueblos en resistencia, Foro Social Temático, Porto Alegre, enero 2012, disponible en http:/ /www.tni.org/es/paper/un-nuevo-periodo-historico Consultado 02/07/2014

Lenton, Diana y Lorenzetti Mariana. Neoindigenismo de necesidad y urgencia: la inclusión de los Pueblos Indígenas en la agenda del Estado neoasistencialista, en Briones Claudia (comp.). Cartografías argentinas: políticas indígenas y formaciones provinciales de alteridad, Buenos Aires, Antropofagia, 2007.

Leone Miguel (2013 a). Leyes indigenistas en la transición democrática. El caso de la ley 426 en Formosa Ponencia presentada en las XIV Jornadas Interescuelas/Departamentos de Historia, Mendoza, Universidad de Cuyo 2 al 5 de octubre de 2013

(2013b). Pueblos originarios y democracia. Conformación de nuevos sujetos políticos. Argentina, 19832013. Observatorio Latinoamericano $\mathrm{N}^{\circ} 12$ UBA- IEALC, pp. 302-320, disponible en http://iealc.sociales.uba.ar/publicaciones/observatorio-latinoamericano/ Consultado: 06/08/2014

EMILIANO, López y Vértiz Francisco. Capital transnacional y proyectos nacionales de desarrollo en América Latina. Las nuevas lógicas del extractivismo neodesarrollista, Revista Herramienta $N^{\circ}$ 50, 2012. Disponible en http://www.herramienta.com.ar/revista-herramienta-n-50/capital-transnacional-y-proyectos-nacionales-dedesarrollo-en-america-latin Consultado: 06/08/2014

Marcha de los Pueblos Originarios Caminando por la verdad, hacia un Estado Pluricultural, 2010. Disponible en http://argentina.indymedia.org/news/2010/05/732875.php Consultado: 08/06/2014

MARTÍNEZ SARASOLA, Carlos. Nuestros paisanos los indios: vida, historia y destino de las comunidades indígenas en Argentina, Buenos Aires, Emecé, 1992.

MURILLO, Susana y Seoane, Jose. Postmodernidad y neoliberalismo. Reflexiones críticas desde los proyectos emancipatorios de América Latina, Buenos Aires, Luxemburg, 2012.

OBSERVATORIO DE DERECHOS HUMANOS DE LOS PUEBLOS INDIGENAS ODHPI Pronunciamiento del ODHPI a propósito de la reforma del Código Civil, 2012. Disponible en http://odhpi.org/codigo-civil/ Consultado 08/06/2014

(2014). Personería jurídica de comunidades indígenas: un fallo clave, en Boletín № 9, Mayo de 2014, disponible en: http://odhpi.org/publicaciones/boletines-mensuales / Consultado 08/06/2014 
PNUD. América Latina, ¿del Neoliberalismo al Neodesarrollismo?, Buenos Aires, PNUD, Siglo XXI, 2013

RODRÍGUEZ DUCH, Darío. La incorporación de la cuestión indígena en la reforma del código civil. Asociación Argentina de Abogados en Derecho Indígena (AADI). Presentación ante la Comisión Bicameral para la Reforma y Unificación del Código civil y Comercial, Buenos Aires, 2012

SEOANE, José y Taddei, Emilio. Recolonización, bienes comunes de la naturaleza y alternativas desde los pueblos, Buenos Aires, Diálogo de los pueblos, Grupo de Estudios sobre América Latina GEA, 2010.

SVAMPA, Mariestela. Extractivismo neodesarrollista, Gobiernos y Movimientos Sociales, en Revista Problèmes de l'Amérique Latine 81, 103-128, 2011

TESLER, Mario. Los aborígenes durante el peronismo y los gobiernos militares, Buenos Aires, Centro Editor de América Latina Serie: Conflictos y Procesos de la Historia Argentina Contemporánea No 21, 1989.

VALKO, Marcelo. Los indios invisibles del Malón de la Paz. Buenos Aires, Ediciones Madres de Plaza de Mayo, 2007.

\section{Leyes}

Ley Nacional de Educación Nº 26.206/ 2006

Ley Nacional 24.071/1992, Aprobación del Convenio 169 de la OIT

Ley Nacional $N^{\circ}$ 23.302/1985 sobre política y apoyo a las comunidades aborígenes

Ley Nacional $N^{\circ}$ 26.160/2006 declaración de emergencia en materia de propiedad comunitaria indígena

Ley Nacional N²6.522/ 2006 sobre Servicios de comunicación audiovisual

Decreto 1184/2002. Reglamentación de la Ley 1800 sobre protección de los pueblos originarios Poder Ejecutivo Provincia de Neuquén.

\section{Prensa}

Página 12 (2013a). El Senado debate las reformas del Código Civil, Buenos Aires, 26 de noviembre

Página 12 (2013b). Fallo de la corte suprema a favor de las comunidades indígenas. Consulta obligatoria, Buenos Aires, 30 de diciembre.

Página 12 (2013c). Último tramo para el nuevo Código Civil y Comercial, Buenos Aires, 15 de noviembre

Página 12 (2013d). Otra cosmovisión para el Código, Buenos Aires, 28 de marzo

Página 12 (2012). La cuestión indígena en la reforma del código civil. Un debate originario, Buenos Aires, 3 de septiembre 
Página 12 (2010). Los Pueblos Originarios plantaron su bandera en Plaza de Mayo, Buenos Aires, 20 de mayo.

Trabalho enviado em 28 de fevereiro de 2015.

Aceito em 16 de maio de 2015. 